УДК 808.2-06(075.8)

DOI: $10.21779 / 2542-0313-2016-31-2-75-78$

\title{
К.Э. Дюкамалов
}

\section{К вопросу о культуре русской речи в полиэтнической среде}

Дагестанский государственный университет; Россия, 367000, г. Махачкала, ул. М. Гаджиева,43a; jalil.samedov@yandex.ru

Статья посвящена проблеме культуры русской речи в поликультурном и полиязычном пространстве Республики Дагестан. Внимание обращается как на теоретические, так и на практические проблемы интерференции в русской речи учащихся-дагестанцев. В качестве методов прогнозирования и преодоления интерференции приводятся типы заданий на занятиях по русскому языку и культуре речи. Актуализируется функциональный аспект использования речевых средств русского языка в полиязычном Дагестане. Обращается внимание и на необходимость соблюдения различных норм русского языка.

Ключевые слова: русский язык, полиэтническая среда, культура речи, интерференция, методика преодоления последствий интерференции.

Русский язык в Республике Дагестан, где функционируют более 30 этносов и языков, является языком межнационального общения. А для значительной части населения и вторым родным языком. В Дагестане как в полиэтническом и поликультурном пространстве вопросы двуязычия и многоязычия приобретают особый характер.

Это особенно касается национально-русского двуязычия, в силу исторических причин ставшего жизненной необходимостью для всех жителей республики. Следует заметить, что сфера применения местных языков в республике весьма ограничена. Родные языки большей частью выполняют функцию общения. Потому овладение только родным языком не представляет в наши дни особого прагматического интереса.

«Языки мира по-разному идентифицируют объекты окружающей действительности. Своеобразие мировосприятия активизируется этносом посредством языка. Наиболее ярко специфика языковой картины мира отражается в топонимах, фразеологизмах, паремиях» [1].

Функциональный статус употребления русского языка как одного из шести мировых языков велик: через русский язык происходит приобщение дагестанцев к мировой культуре. «Различный характер отображения действительности в языках исследователи объясняют тем, что в каждом естественном языке он выступал в виде итогов поразному протекающих в соответствующих языках процессов категоризации и концептуализации мира» $[8$, с. 38$]$.

Большую роль в изучении русского языка, в становлении национально-русского двуязычия играет школа. Именно в школе усваиваются основы русского языка, школа заботится о выработке и соблюдении норм русского литературного языка, передавая их из поколения в поколение.

В условиях поликультурной среды при овладении русским языком остро встает проблема интерференции, т. е. ошибок в русской речи билингвов, обусловленных влиянием родного языка.

Учителя школ, преподаватели вузов на занятиях по русскому языку должны заранее спрогнозировать возможные речевые отключения, погрешности и коммуникативные неудачи, произвести анализ подобных ошибок, поднять уровень орфографической 
и пунктуационной грамотности учащейся молодежи, привить умения четко и ясно выражать свои мысли, говорить правильно и логично.

«Каждая этническая общность отличается специфическими особенностями мировосприятия. Единицы языка разных уровней под влиянием различных факторов могут носить научно-культурный характер, выступая в качестве культурных знаков языка» [7, c. 70].

В настоящее время культура речи, умение общаться, знание этикета являются визитной карточкой любого человека, особенно в деловом мире. Выпускники вузов и особенно колледжей, занимаясь профессиональной деятельностью, часто не имеют представления о специфике общения, его этических нормах, речевом этикете, не владеют правилами создания соответствующего документа [5; 2].

Усвоение теоретических знаний и овладение навыками, входящими в профессиональную составляющую специалиста, а также знаний и навыков, необходимых в практике вуза, является основной задачей курса «Русский язык и культура речи» [2, с. 72].

Русский язык имеет важное практическое значение, успешное его усвоение и целенаправленное практическое применение отражается в речевой культуре [6].

Как известно, речевая культура включает в себя правильность речи и речевое мастерство. Правильность речи - это соблюдение языковых норм (произносительных, лексических, грамматических). Норма современного русского литературного языка воспринимается говорящими и пишущими в качестве образца или общепринятого обычая. Оценки вариантов при этом весьма категоричны и определенны: правильно - неправильно, по-русски - не по-русски, допустимо - недопустимо, допустимо и то, и другое и т. д. Например, неправильно звОнит (вместо звонИт), одел пальто (вместо надел пальто), сколько время (вместо сколько времени), допустимо творОг и твОрог; инАче и Иначе и др. [4].

Речевое мастерство - это и следование нормам языка, и умение выбирать из существующих вариантов наиболее точный в смысловом отношении, стилистически уместный, выразительный, доходчивый [10]. Например, лучше сказать я смог, чем я сумел (о физической возможности, а не об умении), глагол кушать не употребляется в форме 1 лица: нельзя сказать я кушаю (правильно: $я$ ем) и т. д. Поэтому важнейшим в культуре речи мы считаем нормативный аспект, т. к. основное свойство нормы - это ее обязательность для всех говорящих и пишущих.

Существуют три степени нормативности: норма первой степени - строгая, не допускающая вариантов, например, чулок (не чулков), носков (не носок), класть (не ложить), диспансЕр (не диспАнсер), новый тюль (не новая тюль) и т. д.; норма второй степени - менее строгая, допускающая равноправные варианты, например, npAвы и правЫ, одноврЕменно и одновремЕнно и т. д.; норма третьей степени - наиболее подвижная, один вариант является основным, второй - разговорным, например: красИвее (а не красивЕе), ляг (а не ляжь), чашка чая (а не чаю), договОры (а не договорА) и т. д.

Следовательно, необходимо не только знакомить студентов с речевыми ошибками, но и на каждом занятии проводить планомерную, систематическую работу как с нормативным, так и с ненормативным языковым материалом, выполнять разнообразные задания типа:

а) поставить ударение в следующих словах: кремень, квартал, туфля, танцовщииияа, вероисповедание, маркетинг, одновременно, обеспечение, торты, тосты, ходатайствовать, оптом, оптовый и т. д.;

б) объяснить значение следующих слов: скрытый - скрытный, вперемежку вперемешку, иммигрант - эмигрант, компания - кампания, эффектный - эффективный и т. д.; 
в) придумать предложения со словами: нота, брак, коса, дипломат - дипломант - дипломник, акция, повод и т. д.;

г) объяснить значение фразеологических оборотов и составить с ними предложения: лебединая песня, стреляный воробей, курам на смех, играть первую скрипку, крокодиловы слезы, казанская сирота, гордиев узел, во всю ивановскую и т. д.;

д) отделить правильные сочетания от неправильных: коренной абориген, информационное сообщение, смельй риск, первый пионер, внутренний интерьер, памятный сувенир, монументальное искусство, толпа людей, народный фольклор и т. д.;

е) определить род существительных: тюль, толь, лазурь, тишь, шампунь, мозоль, шинель, вестибюль, алиби, слуга, резюме, пони, вышибала и т. д.

ж) составить словосочетания с данными словами: беспокоиться (о ком-л.), тревожиться (за кого-л.), удивляться (чему-л.), отчитаться (в чем-л.), предостерегать (от чего), проявлять внимание (к чему) и т. д.

Что касается современного состояния речевой культуры в республике, то следует отметить, что этому вопросу уделяется большое внимание: проводятся международные и региональные конференции, во всех учебных заведениях изучается курс «Русский язык и культура речи», в печатных средствах массовой информации часто публикуются материалы по культуре русской речи, в Дагестанском государственном университете ежегодно в апреле по результатам проведенных конференций издаются сборники статей «Русский язык и литература в школе и вузе» и т. д.

\section{Литература}

1. Айвазян O.O. Коммуникация и речь // Вестник Адыгейского государственного университета. Сер. Педагогика и психология. - 2012. - Вып. 3 (103).

2. Введенская Л.А. и др. Русский язык и культура речи: учебное пособие для вузов. - Ростов н/Д, 2004.

3. Гасанова С.Н., Ванатиева Н.Г. Метафора в топонимах агульского языка // Вестник Дагестанского государственного университета. - 2014. - Вып. 3.

4. Голуб И.Б. Русский язык и культура речи: учебное пособие. - М., 2002.

5. Есакова М.Н., Кольцова Ю.Н., Литвинова Г.М. Русский язык и культура речи. Нормы современного русского литературного языка: учебное пособие. - М.: Флинта, 2012.

6. Ипполитов Н.A. и др. Русский язык и культура речи. - М., 2006.

7. Исаева Э.М. Концепт «любовь» в аварской языковой картине мира // Вестник Дагестанского государственного университета. - 2015. - Вып. 3. 2012.

8. Кубрякова Е.С. В поисках сущности языка. Когнитивные исследования. - М.,

9. Кудрявцева Е.Л., Волкова Т.В., Якимович Е.А. Обучение русскому языку в билингвальной среде: методические рекомендации. - М., 2013.

10. Невежина М.B. и др. Русский язык и культура речи: учебное пособие. - М., 2015. - C. 48.

11. Пекарская И.В. и др. Речеведение. - Абакан: Хакасский государственный университет, 2013.

12. Русский язык и культура речи / под ред. проф. Максимова В.И. - М., 2009.

Поступила в редакиию 25 марта 2016 г. 
UDC 808.2-06(075.8)

DOI: $10.21779 / 2542-0313-2016-31-2-75-78$

\section{On the problem of the Russian speech culture in multiethnic society}

\section{K.E. Dzhamalov}

Dagestan State University; Russia, 367001, Makhachkala, M. Gadzhiev st., 43a; jalil.samedov@yandex.ru

The article is devoted to the problem of the Russian speech culture in multicultural and polylingual space of the Republic of Dagestan. The attention is paid to both theoretical and practical problems of interference in the Russian speech of Dagestan students. Various tasks are set at the lessons of the Russian language and culture of speech to forecast and overcome the interference. The functional aspect of using speech means of the Russian language is actualized in polylingual Dagestan. The attention is also drawn to the necessity of observing different norms of the Russian language.

Keywords: the Russian language, multiethnic society, culture of speech, interference, methods of overcoming the interference effect.

Received 25 March, 2016 